DEPARTMENT OF THE INTERIOR

UNITED STATES GEOLOGICAL SURVEY GEORGE OTIS SMITH, DIRECTOR

Water-Supply Paper 345-C

\title{
UNDERGROUND WATER OF LUNA COUNTY NEW MEXICO
}

BY

\author{
N. H. DAR'TON
}

WITH

RESULTS OF PUMPING TESTS

By A. T. SCHWENNESEN

Contributions to the Hydrology of the United States, 1914-C

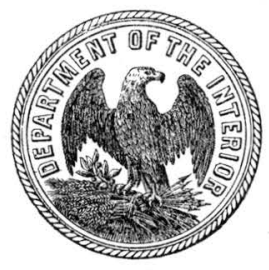

WA SHINGT ON

GOVERNMENT PRINTING OFFICE

1914 


\section{CONTENTS.}

Page.

Introduction................................................ 25

General conditions.............................................. 25

Extent of underground water..................................... 26

Source of underground water................................... 26

Thickness of water-bearing beds................................... $\quad 27$

Volume of underground water.................................. 28

Rate of underflow........................................... 29

Depletion of supply........................................ 29

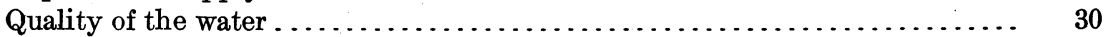

Wells..................................................... 30

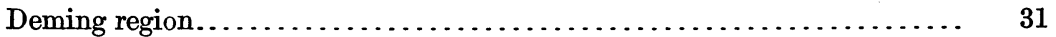

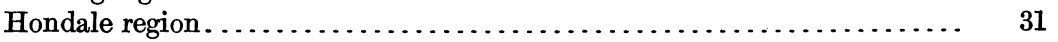

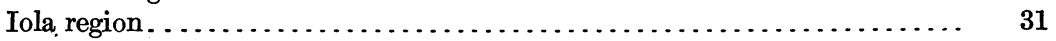

Waterloo region............................................. 31

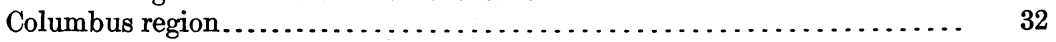

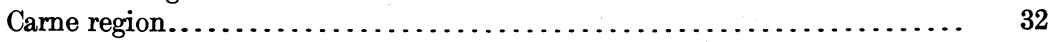

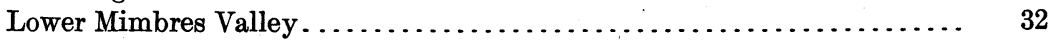

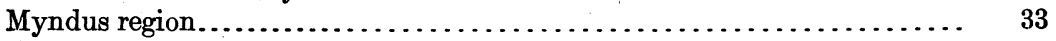

North-central townships.................................... 33

Region west of Red Mountain............................... 33

Spalding region.............................................. 34

West-central townships..................................... 34

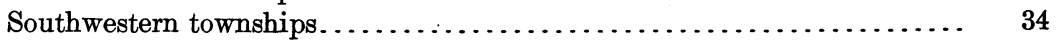

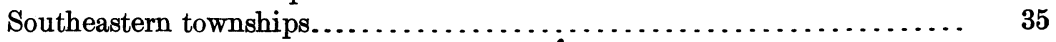

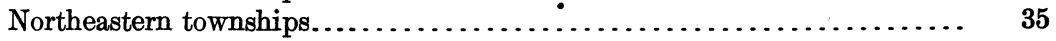

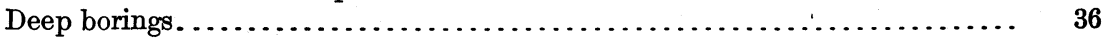

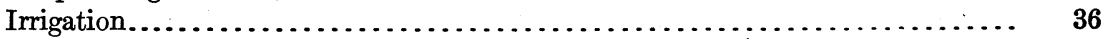

Results of pumping tests, by A. T. Schwennesen................... 37

\section{ILLUSTRATION.}

Prate II. Map showing water conditions in part of Luna County, N. Mex.... 


\title{
UNDERGROUND WATER OF LUNA COUNTY, NEW MEXICO.
}

\author{
By N. H. Darton.
}

\section{INTRODUCTION.}

This paper is an abstract of part of an extended report on the geology and water resources of Luna County now in preparation by the Survey. It is issued to meet the urgent demand for information regarding wells and prospects for underground water in Luna County, especially as to the limits of the area in which the water is available for irrigation. The facts were obtained by investigations made in 1910, with a supplemental canvass for data of new wells in 1911, 1912, and the summer of 1913.

During the last few years a large number of homesteaders have taken up lands in the broad, level bolsons of Luna County with the expectation of pumping underground water for irrigation. They have been encouraged by the excellent results obtained by a few earlier settlers, and many of them have sunk wells and installed pumping plants and have already obtained satisfactory returns from irrigation.

\section{GENERAL CONDITIONS.}

The thick body of sand and gravel underlying the wide bolsons of Luna County contains a very large volume of water, most of which is within 20 to 150 feet of the surface. The depth and volume of water vary from place to place, but there are extensive areas in which the depth is not too great for profitable pumping and the volume is ample for irrigation. Unfortunately, there are also large areas in which the water lies too deep or is too scanty in amount, and many settlers have been or are likely to be located where they can not possibly obtain an adequate supply. One of the principal purposes of the investigation, therefore, was to determine the extent, depth, and capacity of the water-bearing deposits. In a large part of the region the underground relations have been determined by the sinking of numerous wells, but in some sections but little information is available. The map (Pl. II) presents the more important general conditions so far as they could be determined from the data obtainable. 
In the following pages will be given a brief account of representative wells and a condensed review of the local conditions, the detailed statements being reserved for the report which is to appear later.

\section{EXTENT OF UNDERGROUND WATER.}

By far the largest volume of water in Luna County is under the broad bolson extending southward from Deming to the foot of the Tres Hermanas Mountains and thence southeastward through the gap between that range and the Florida Mountains to the Palomas Lakes, in Mexico. Most of the wells in T. 24 S., Rs. 8 and 9 W.; T. 25 S., R. 9 W.; and T. 26 S., Rs. 9 and 10 W., and the valley of Palomas Arroyo find, at depths of 50 to 200 feet, a large supply of water which rises within 20 to 60 feet of the surface. The limits of the area in which this favorable condition exists is a matter of great practical importance to settlers, for outside of the area containing an adequate supply of ground water the land is of no value for agriculture. Unfortunately the underground conditions in the bolson deposits are difficult to determine without records of many wells, and in some places where data of that sort are lacking the limits of water-bearing strata can not be located with precision. The Florida Mountains and other rock ridges delimit much of the area, but the form of the rock slopes under the bolson deposits is not indicated at the surface. Doubtless also there are underground many small ridges of rock which are similar to those outcropping in Snake Hills, Midway Buttes, and several other exposures, and which approach so near the surface as to cut off the underflow. On the map (Pl. II) these underground-water conditions are set forth so far as information is available. Undoubtedly a large part of the area shown on this map with the legend "Water conditions not determined" is barren of serviceable underground supplies, and the greater parts of the areas in which the water surface is more than 60 feet below the surface do not contain water in large volumes. The broad basin south of Cedar Grove Mountain contains but little water, and the great sink of Mimbres River east of the Florida Mountains appears to have but a scanty water supply. In the district lying between Cooks Range and the Goodsight Mountains the conditions appear to be favorable for good ranch supplies, but they have not been adequately tested. The water is considerably deeper here than in the Deming region.

\section{SOURCE OF UNDERGROUND WATER.}

It is a popular belief that the water contained in the sand and gravel under the great bolsons of Luna County is the underflow of Mimbres River, but it has been found that this stream supplies only a 


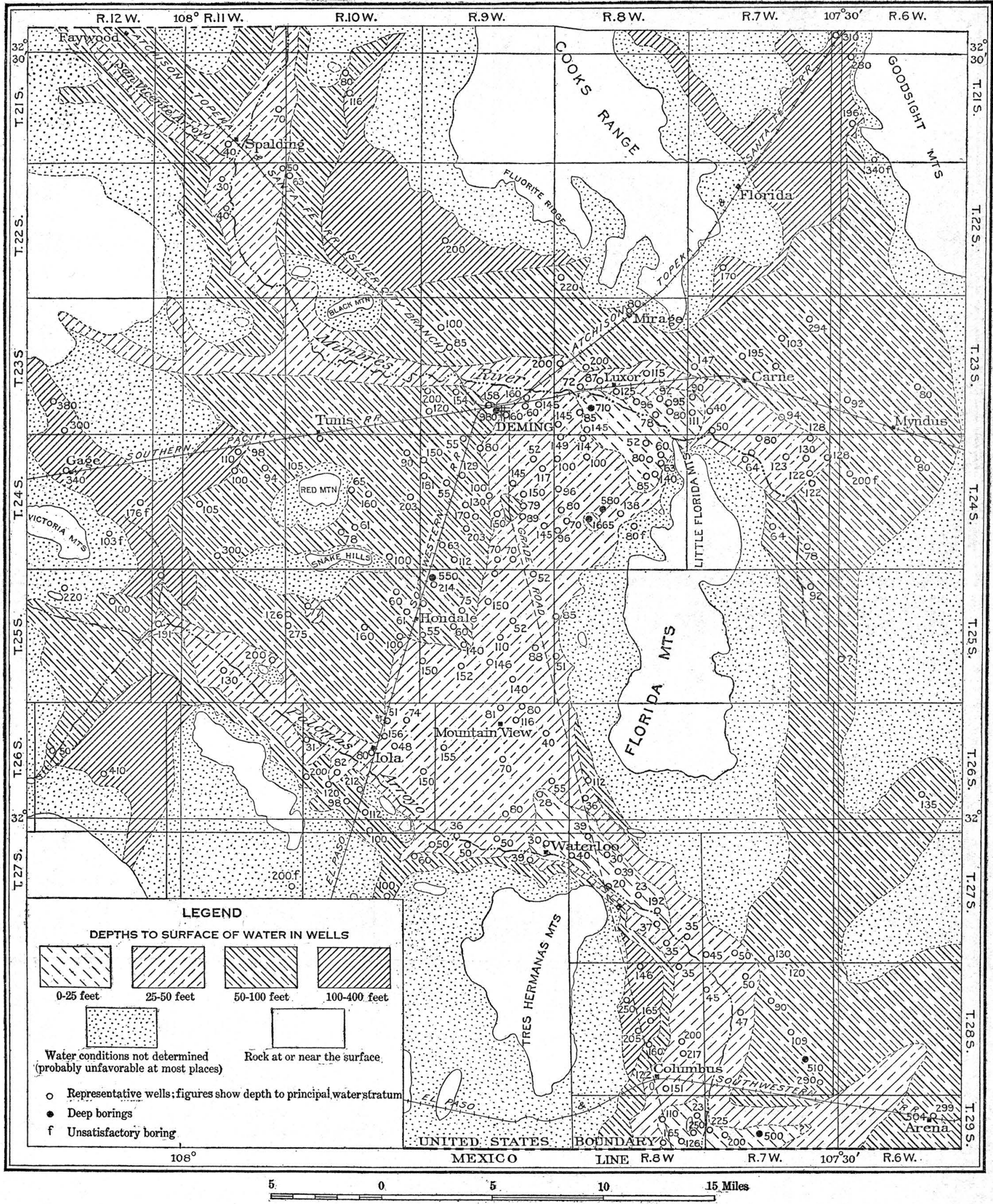

MAP SHOWING WATER CONDITIONS IN PART OF LUNA COUNTY, N. MEX. 
small proportion of the ground water. The rainfall is about 10 inches a year, and although a large part of the rainwater evaporates, some of it passes underground. There is no run-off in the bolsons except after a "cloud-burst," when water flows to the lower ground and either evaporates or sinks. Considerable water runs off from the mountain slopes, flowing out upon the bolsons. Mimbres River brings into the region a certain amount of water, which it gathers from the mountains to the north, and this water and part of the rainfall have been passing underground for a very long time. The water from these sources fills the interspaces in the gravel and sand deposits underlying most of the wide bolson about Deming and to the south.

As the amount of rainfall water which passes underground in the region is unknown, it is not possible to give figures as to the rate at which the water accumulates in the bolson deposits. The loss by evaporation is so great that possibly only 2 or 3 inches of the annual rainfall passes underground. The amount of water annually received by the bolson deposits from the underflow of Mimbres River, the Arroyo San Vicente, and a few other streams flowing out of the highlands is very difficult to ascertain. As these waters probably spread out widely in the coarse sands and gravels of the bolson, the yearly increment from this source is only a few inches to the acre. Gagings of Mimbres River from 1908 to 1913 at the dam site above Spalding indicate an annual flow ranging from about 3,270 to 30,000 acre-feet, and averaging considerably less than 10,000 , and there is a small additional underflow. This water passes underground a few miles south of the gaging station. If its volume is estimated at 12,000 acre-feet, and it spreads out under the 14 townships contiguous to the line of its southward flow underground to the Palomas Lakes, it would give an annual increment of less than half an inch.

\section{THICKNESS OF WATER-BEARING BEDS.}

The deposits which underlie the bolsons of Luna County vary greatly in their capacity to hold water, not only from bed to bed but in a single bed from place to place. They include many strata or beds of sand, and some of the records show that these beds attain locally a thickness of 40 to 50 feet. In most places, however, their thickness is much less, and many of the borings reveal some admixture of clay. Some representative sections are given in the following paragraphs to show the thickness of water-bearing beds in various parts of the region about Deming.

At the Hicks well, in the northwest corner of sec. 7, T. 24, R. 8, the main water-bearing stratum extends from 46 to 100 feet, having a thickness of 54 feet, and there was more or less sand from 100 to 150 feet. Half a mile south of this well the first water is in 5 feet of sand and gravel, the second water in $\mathbf{1 4}$ feet of sand and gravel, and the 
third in 6 feet of sand, extending from 111 to 117 feet, which gives a total of 25 feet of water-bearing beds. South of this place, in the McBride well, 6 miles southeast of Deming, nearly all the water is in gravel and sand at 45 to 54 feet, clay extends from 54 to 67 feet, and sand containing considerable water from 67 to 96 feet. From 96 feet to the bottom at 161 feet the deposit is reported to be clay.

At the Shull well, 4 miles southeast of Deming, there are three water-bearing beds. The upper two are thin strata of sand and gravel; the lowest one, extending from 140 to 156 feet, has a yield stated to be 1,250 gallons a minute.

In the Paxton well, 6 miles east of Deming, the first water stratum is 3 feet of sand, the second 22 feet of sand, and the third stratum, which yields the main supply, is 9 feet of sand, extending to a depth of 96 feet.

In the Foulk well, 3 miles south by east of Deming, the waterbearing sands are only about 5 feet thick and are separated by clay. Two miles west of this well the water-bearing strata are 7, 4, and 14 feet thick, and at the Young well, a mile farther south, or 6 miles southwest of Deming, all the water is obtained from a stratum extending from 55 to 75 feet, no water being found below this stratum to the bottom, at 203 feet.

At a 70-foot well 3 miles northwest of Deming the water is derived from a 6 -foot gravel bed near the bottom.

The few deeper borings that have been made show relatively few beds of water-bearing sand below 200 feet, so there is but little prospect of great increase in supply with increase in depth.

\section{VOLUME OF UNDERGROUND WATER.}

As the water-bearing deposits vary greatly in thickness, texture, and continuity from place to place, it is difficult to determine accurately the amount of water stored in the deposits, and only an approximate estimate can be offered as to the annual increment. It would appear that in most parts of the region around Deming and to the south the average aggregate thickness of the waterbearing beds in the first 150 or 200 feet below the surface is about 40 feet. Assuming that the water in these sand beds amounts to 20 per cent of their volume, which is a fair average, we find that the quantity of water in a given area would be nearly 8 cubic feet to the square foot, equivalent to 60 gallons, or approximately 8 acrefeet to the acre. This is much more than the amount obtainable, because it is impossible to pump out all the water, the proportion available depending on the texture of the sand and some other minor factors.

The area in this region under which lie 40 feet of water-bearing beds containing a fair volume of water covers about 500 square 
miles, and if this volume is 8 cubic feet to the square foot, the underground water supply in that area is 2,560,000 acre-feet. Besides this area of 500 square miles there is a region of large extent containing a moderate volume of underground water, some of which can be utilized for irrigation.

It is impossible to make an accurate estimate of the time required for the accumulation of such an amount of water, or for its restoration if the stored-up supply were pumped out. The annual increment from rainfall undoubtedly amounts to a few inches, the amount varying with the porosity of the surface deposits. The Mimbres underflow of 12,000 acre-feet, as above estimated, passing under the 14 townships that are in the line of its travel southward, would amount to an annual increment of less than half an inch for that area. At this rate many years would be required to fill the voids in the 40 feet of water-bearing beds.

\section{RATE OF UNDERFLOW.}

The word "underflow" implies a movement of the water down a slope of greater or less amount, and the gradient and the porosity of the materials traversed are the principal factors bearing on the rate of flow.

At Spalding the water is 30 feet below the surface, or 4,698 feet above sea level. At Deming it is 50 feet below the surface, or 4,290 feet above the sea, and at Columbus it is 30 feet below the surface, or at an altitude of about 4,033 feet. As the distance from Spalding to Deming is 17 miles, the gradient between the two places is about $24 \frac{1}{2}$ feet to the mile. The distance from Deming to Columbus being $31 \frac{1}{2}$ miles, the gradient in that distance is 8.3 feet to the mile. At Iola the water is 46 feet below the surface, or 4,154 feet above sea level, a gradient of slightly more than $7 \frac{1}{2}$ feet to the mile from Deming. At Gage the water is 26 feet lower than at Deming, probably because the upper beds are too fine to admit any notable volume of water. The rate of movement of water is very slow with these low gradients and in materials so fine as those constituting the water-bearing strata of this region. No measurements have been made, but to judge from determinations in other regions the rate of movement is less than a mile a year, and it may be as low as a mile in two years.

\section{DEPLETION OF SUPPLY.}

Nearly 200 pumping outfits are installed or under erection in the Deming-Columbus region, and it is expected that the average output of each one will be about 700 gallons a minute for about 400 hours a year. If the number of pumps were 500, which, however, is probably far beyond the financial ability of the settlers now on the ground, the total yearly pumping of water for irrigation would be 8.4 billion 
gallons, or nearly 26,000 acre-feet. This would be equal to water 2 feet deep on 20 square miles, and with this amount or duty of water at 2 acre-feet per acre a season, 20 square miles to 500 ranches is equivalent to an average of only about $25 \frac{1}{2}$ acres under ditch to each quarter-section homestead. As 500 homesteads ordinarily occupy an area of 125 square miles, the 26,000 acre-feet would be drawn from that area at the rate of about one-third acre-foot of water annually, or less than 4 per cent of the estimated 8 acre-foot supply. An annual increment by rainfall and underflow of 3 inches would be sufficient to provide for the irrigation of only about one-eighth of the area in which the underground storage conditions are favorable, on the basis of duty of water as 2 acre-feet per acre ( 2 feet deep over the area irrigated each season).

Of course 20 square miles under cultivation as above estimated is a small proportion of the 125 square miles, or area of 500 homesteads, under consideration, nearly all of which could be irrigated by plants with an average output of 700 gallons a minute. Eventually no doubt the proportion of land utilized in each homestead will increase, as it must for profitable operation, and then the draft on the underground supply will increase proportionally. If half of the area of every homestead were irrigated the draft on the underground supply would be about 12 per cent instead of 4 per cent, which would cause a serious diminution in the total amount available in some areas. Wells too closely placed and drawing heavily would also deplete the supply locally, as the rate of lateral movement is very slow.

\section{QUALITY OF THE WATER.}

In general the water from wells in Luna County is of excellent quality, in every way suited for all uses. At a few places along the margin of the bolsons where rocks are near the surface and in the valley east of the Florida Mountains there is considerable mineral matter in the water, but this is an unusual feature. The water pumped for domestic use and irrigation about Deming and to the east and south is of notable purity. However, all ground water contains some mineral matter, and if large volumes are allowed to evaporate on the land this matter will accumulate as "alkali" in or on the soil and finally render it unfit for plant growth.

\section{WELLS.}

There are about 280 wells of various kinds in Luna County, most of them sunk within the last five years, and considerable well drilling is still in progress. Most of the wells are south and east of Deming, the largest number of them being in Tps. 24 and 25 S., R. 9 W.; T. 24 S., R. 8 W.; and the south halves of T. 23 S., Rs. 8 and 9 W. There are also groups of wells near Hondale, Iola, Waterloo, and Columbus. 
The location of representative wells and the depth to the principal water stratum are shown by figures on Plate II (p. 26), and the map also indicates areas in which water in wells rises to different levels within 400 feet of the surface. It has been found somewhat difficult to obtain complete data for all the wells in Luna County, and for some wells the figures given by driller and well owner are not the same.

Deming region.-In the region immediately about Deming and for some distance to the east and south there are many wells which obtain large supplies of water. Their depth is, as a rule, less than 150 feet, the deeper ones reaching lower sand strata which ordinarily contain the largest volume of water. Many of the wells yield from 800 to 1,200 gallons a minute. The water rises within 20 feet of the surface in the area 5 miles southeast of Deming, but the depth gradually increases to 45 or 50 feet in and south of Deming, to 60 or 65 feet southwest of the city, and to 90 feet northwest of it. In the northern part of T. 23 S., Rs. 8 and 9 W., the conditions are less satisfactory, for the water strata are deeper, there is much quicksand, and the water does not rise as near to the surface. A few wells in this area, however, yield moderately satisfactory supplies. Southeast of Deming there is an abundance of water, except on the slope of the Little Florida Mountains, where the main water-bearing beds cease.

Hondale region.-There are many wells about Hondale and between that place and the foot of the west slope of the Florida Mountains. They are from 100 to 150 feet deep in greater part and all obtain large supplies of excellent water, which rises within 30 to 60 feet of the surface, the depth increasing from east to west. Many of the wells pump more than 1,000 gallons a minute. The same water conditions continue for some distance west of Hondale, but the strata finally become more irregular in that direction and at some places it has been necessary to sink more than 200 feet to obtain satisfactory wells. The Snake Hills, which rise out of the bolson 6 miles northwest of Hondale, locally interrupt the extension of the water-bearing beds in that direction.

Iola region.-There are a few excellent wells about Iola, but in places rock comes near to the surface and cuts off the main underflow. Wells along Palomas Arroyo from the 76 ranch to Waterloo and beyond yield satisfactory supplies, but south of that arroyo there have been numerous borings with unfavorable results. Several wells with large capacity have been put down about Mountain View, 6 miles northeast of Iola, and favorable conditions appear to exist in all parts of T. 26 S., R. $9 \mathrm{~W}$.

Waterloo region.- The underground waters are near the surface at Waterloo and for some distance to the north, east, and southeast of that place. Mast of the wells in this vicinity are only from 35 to 40 $39836^{\circ}-14-2$ 
feet deep, and water in them rises within 18 to 25 feet of the surface. The area in which this condition exists is shown on Plate II (p. 26). The wells pump from 500 to 1,000 gallons a minute and yield ample supplies for extensive irrigation. The water-bearing strata are cut off to the south by the slopes of the Tres Hermanas Mountains and probably do not extend far east of Palomas Arroyo, but they underlie this arroyo and a narrower zone of adjoining plains extending southeastward through T. 27 S., R. 8 W.

Columbus region.- Underground water is extensively developed about Columbus, in the wide bolson traversed by Palomas Arroyo. The wells range in depth from 25 to 200 feet and obtain water which rises within 2 feet of the surface near the international boundary, but only within 50 feet or more in the region farther north. The volume of water varies greatly from place to place, some of the wells south and southeast of Columbus yielding from 500 to 2,000 gallons a minute, while others have much less capacity, the supply in some areas being very scanty. The underground conditions present great diversity, especially in the existence of thick bodies of quicksand, which appear to choke up the strata in parts of the area 5 miles southeast, east, and northeast of Columbus. One 510-foot boring 7 miles east of Columbus obtained an artesian flow, but for some unknown reason this flow did not continue. In the slopes west, north, and northwest of Columbus the waters are deep and not in great volume. The strata are finally cut off in those directions by the Tres Hermanas Mountains.

Carne region.-The favorable underground-water conditions found about Deming extend down the Mimbres Valley through the south half of T. 23 S., R. 7 W., and the northeastern part of T. 24 S., R. 7 W. There are in this region numerous wells 50 to 150 feet deep yielding large volumes of water. The water rises within 16 feet of the surface near the river banks 4 miles southwest of Carne, and, while the depth increases gradually to the east and south, it is only 50 feet in the center and northeast corner of T. 24 S., R. 7 W. Farther south the conditions are less favorable, for the volume of water diminishes and its quality is not so good. In the region north of Carne the strata are variable, and while several excellent wells have been obtained, others are unsatisfactory. A 294-foot well 4 miles northeast of Carne found several promising beds of sand, but their yield was not ascertained.

Lower Mimbres Valley.-In the wide bolson valley east and southeast of the Florida Mountains the conditions for large supplies of underground water appear to be unfavorable at most localities. Many test holes from 100 to 375 feet deep have been sunk, and most of these. have found quicksand yielding little or no water or water of saline character. The district is a basin into which Mimbres River spreads out as a lake in times of exceptional freshets, depositing fine sediments 
on evaporation. Evidently this condition has continued for a long time, as most of the materials pierced in boring are fine and contain minerals resulting from evaporation. The old well 92 feet deep at the Birchfield ranch, in the northeastern part of T. $25 \mathrm{~S} ., \mathrm{R} .7 \mathrm{~W}$., yields a good supply of stock water, but the water carries considerable saline matter. A well recently sunk to a depth of 160 feet at this place obtained water that is less mineralized. Another well 5 miles down the valley yields fairly good water, but several borings 275 to 375 feet deep east and west of it found quicksand with but little water or water containing much salt. A 135-foot well in the southeastern part of T. 26 S., R. 6 W., obtains a small volume of saline water.

Myndus region.-A few wells sunk north and west of Myndus siding have found the water at about the same depth as in the region northeast of Carne, but the volume is less. At a ranch 3 miles northwest of Myndus a 92-foot well, all in hard clay, contained only 2 feet of water and yielded about 3 gallons a minute. An 80-foot well 3 miles northeast of Myndus contains only 5 feet of water and its capacity, though not yet ascertained, appears not to be great. A 275-foot boring $1 \frac{1}{2}$ miles to the north is reported to have found a good volume of water, which rises within 80 feet of the surface, but it is lowered to 250 feet by pumping at the rate of 250 gallons a minute.

North-central townships.-In the region adjoining the southwest slope of Cooks Range and Fluorite Ridge the bolson deposits apparently lie on a very irregular floor and water conditions vary greatly from place to place. The few wells sunk in this region have not developed a large water supply. The most notable well is one 220 feet deep in the southwest corner of T. 22 S., R. 8 W., which afforded the supply for the camp at the Fluor mine and appeared to contain a fairly large amount of water. The water rises within 80 feet of the surface and is pumped by a windmill.

Region west of Red Mountain.--Several wells north and northwest of Red Mountain or between that mountain and the Southern Pacific Railroad obtain satisfactory water supplies, but farther west and south the conditions appear to be less favorable. A 300-foot boring 6 miles southwest of Red Mountain obtained too small a volume to be serviceable. The amount available in the wells north and northwest of Red Mountain has not been fully determined, but one of these wells is reported to yield 100 gallons a minute without materially lowering the water; this indicates a fairly large supply. In the low land in the southwestern part of T. 24 S., R. 11 W., the water conditions may be favorable for a moderate supply, as indicated by a good well a short distance to the south, in the next township. A new well in the northwest corner of sec. 21 is reported to have found water-bearing sand at a depth of 95 to 105 feet, from which water rises within $86 \frac{1}{2}$ feet of the surface. 
Spalding region.-There appears to be a widespread body of waterbearing materials under the region adjoining Mimbres River about Spalding and for some distance to the south, toward Black Mountain. Many wells have been sunk in this district and, according to report, they are capable of yielding large volumes of water. The large 70foot well at the ranch 3 miles northeast of Spalding has been tested to a reported yield of 800 gallons a minute. The limits of the area underlain by the water-bearing strata in this vicinity have not been determined, but these strata terminate near the rocky region in T. $22 \mathrm{~S}$., R. $12 \mathrm{~W}$., and to the east near the outlying ridges of Cooks Range.

West-central townships.-At Gage station the railroad company has two wells, one 330 feet deep and the other 340 feet deep, in which the water rises within 225 feet of the surface. The capacity of each well is 30,000 gallons in a day of 24 hours. A mile and a half farther north two windmills draw from wells 300 feet deep in which the water rises within 270 feet of the surface. Their capabilities are not known, but they afford water for stock. The well at Van Meter's ranch, 3 miles north of Gage, is 380 feet deep, with water 310 feet below the surface. Originally the water rose to about 304 feet below the surface, but it has been gradually pumped down in supplying water for stock and domestic service. Four miles west of Van Meter's is a boring 381 feet deep that failed to obtain water. The bolsons in this region are underlain by a thick deposit of clay with many layers of sand and gravel, but the water is deep and the supply meager. Possibly deeper wells might develop additional amounts of water. In the 191-foot well at the Jordan ranch, near the Palomas Arroyo, in the SW. $\frac{1}{4}$ sec. 18 , T. 25 S., R. 11 W., the water rises within 38 feet. of the surface, and the well has an estimated capacity of 400 gallons or more a minute. At the Todhunter ranch, in the SW. $\frac{1}{4} \mathrm{NW} \cdot \frac{1}{4}$ sec. 11, T. 24 S., R. 12 W., a 100-foot well supplies water for stock. It entered the water-bearing sand at 75 feet and the water rises within 75 feet of the surface. At another ranch, in the SW. $\frac{1}{4}$ NW. $\frac{1}{4}$ sec. 12 , T. 25 S., R. 13 W., a well 150 feet deep has water about 100 feet below the surface, yielding about 15 gallons a minute when pumped by windmill for stock use. A 220 -foot boring made in the shallow dry-lake basin just north of the mound of rhyolite halfway between these two ranches obtained no water at all, a result which probably indicates that there are no water supplies in the slopes south of the Victorio Mountains. A 103-foot well in the W. $\frac{1}{2}$ sec. 26, T. $24 \mathrm{~S} .$, R. $12 \mathrm{~W}$., and a 116-foot well 2 miles northeast of that place failed to obtain water, but they were not sufficiently deep to reach beds in which water is to be expected.

Southwestern townships. - In the wide basin lying between the Cedar Grove Mountains and Sierra Rica there is a thick mass of bolson deposits which contain more or less water, but so far as they 
have been tested the water is far below the surface. The well a mile south of Victorio station is 430 feet deep, and the supply at that depth is not great. Six miles farther southeast, near the international boundary, there is a well 320 feet deep which affords a satisfactory supply of water for stock. A shallow well at the Williams ranch, at the foot of the Cedar Grove Mountains, yields a fair amount of excellent water, probably from agglomerate. North of the Cedar Grove Mountains the water conditions are variable. At the Klondike ranch, near the center of T. 26 S., R. 12 W., it was necessary to sink 410 feet for a moderate supply of water, which rises within 375 or 380 feet of the surface. It is pumped by a windmill, but when this raises more than 9 gallons a minute, the water draws down rapidly. In the arroyo $2 \frac{1}{2}$ miles west-northwest of this ranch there is a well 50 feet deep in which water rises within 40 feet of the surface, affording a supply sufficient for stock. Three miles farther up the valley, at a point just south of the Klondike Hills, a shallow well obtained water, but the supply was inadequate.

Southeastern townships.--The water conditions in the southern part of Luna County east of $R .7 \mathrm{~W}$. are not fully ascertained. Most of the area is underlain by sand and gravel which contain water, but the amount appears not to be large. Several wells on the Birchfield ranches, one just east of Arena and the other 6 miles northeast of Arena, obtain small supplies, but the depths of wells and water could not be learned. The railroad company has recently made a boring 504 feet deep at Arena and found no water below the main supply at 299 feet, which rose within 66 feet of the surface. The volume was tested and found to be 100 gallons a minute, but as the water was unsuited for locomotive use the well is not in service. There are some old wells that supply windmills in the north-central part of $T$. $27 \mathrm{~S} .$, R. $6 \mathrm{~W}$., and the eastern part of the next township north, 5 or 6 miles west of the Birchfield ranch, but their depths and the depth to water could not be ascertained. They afford water for stock.

Northeastern townships.--While the underground-water conditions in the region east of Cooks Range and the Goodsight Mountains are somewhat diverse, there is but little prospect of obtaining large supplies such as are found about Deming. In the valley east of the Goodsight Mountains there are several good wells for stock use and garden irrigation. These wells are 80 to 225 feet deep, and the water is far below the surface.

Several wells have been bored along the west side of the Goodsight Mountains and near the railroad, northeast of Florida. The water is deep and while in most wells it is sufficient in volume for ranch use it is not available for extensive irrigation. 


\section{DEEP BORINGS.}

Several deep borings have been made in Luna County with the hope of finding artesian flows, but the results have not been satisfactory.

One boring 6 miles southeast of Deming was 1,665 feet deep, but below 520 feet the materials were so compact that they yielded little water. The water at 520 feet came within 17 feet of the surface and, with that from higher strata, afforded an ample supply for pumping. A 710-foot boring $3 \frac{1}{2}$ miles east of Deming is reported to have obtained a small flow which lasted for a short time, but finally only the shallower waters were utilized. In a 980 -foot boring in Deming the water came within 9 feet of the surface, but the principal supply was obtained at a moderate depth.

It is asserted that a depth of nearly 1,000 feet was reached at the Shay ranch, 7 miles northeast of Columbus. Water was found at intervals all the way'down and came within 15 feet. of the surface. A 510-foot well recently sunk 7 miles north-northeast of Columbus found a flow which lasted awhile but finally ceased for some unexplained reason.

It is not at all unlikely that a deep boring to the bottom of the materials filling the bolson might develop a large artesian flow, but there is no assurance that such a boring would be successful.

\section{IRRIGATION.}

The more extended report on Luna County will contain a brief account of irrigation by well water in various parts of the county. Many of the wells are equipped with pumps capable of delivering from 500 to 1,500 gallons a minute, and at some of the ranches considerable irrigation has been done already, with very satisfactory results as to products and cost. The wells for this service are mostly from 100 to 200 feet deep and have water from 20 to 50 feet below the surface. Naphtha is the fuel at most of the plants, but crude oil has been employed at some and found much cheaper, and electricity carried by wires from Deming is used at a number of places. There are many irrigation plants near Deming, Carne, Hondale, Mountain View, and Waterloo and south of Columbus, and while the area irrigated ranges from a quarter section of 160 acres to a small garden plot, the extent of land under cultivation is generally from 20 to 40 acres. The amount of water used varies considerably. It is generally agreed that 30 inches, or $2 \frac{1}{2}$ acre-feet per acre, is desirable, but less than this amount will serve if the water is properly applied and the ground is carefully cultivated. Much depends on the soil, which varies from sand to almost impervious silt, and there is also some range in the character of the subsoil. The rainfall, snowfall, nature 
of winds, arrangement of ditches, and amount of water immediately available are important factors.

The following table gives a summary of the cost of pumping for irrigation at a number of places in Luna County:

Cost of pumping at irrigation plants in Luna County, N. Mex.

\begin{tabular}{|c|c|c|c|c|c|}
\hline Locality. & $\begin{array}{c}\text { Lift } \\
\text { (feet). }\end{array}$ & $\begin{array}{c}\text { Reported } \\
\text { yield (gal- } \\
\text { lons a min- } \\
\text { ute). }\end{array}$ & $\begin{array}{c}\text { Cost of fuel } \\
\text { per acre- } \\
\text { foot. }\end{array}$ & $\begin{array}{c}\text { Approxi- } \\
\text { mate cost } \\
\text { per acre- } \\
\text { foot per foot } \\
\text { raised } \\
\text { (cents). }\end{array}$ & $\begin{array}{l}\text { Fuel and cost per } \\
\text { gallon. }\end{array}$ \\
\hline 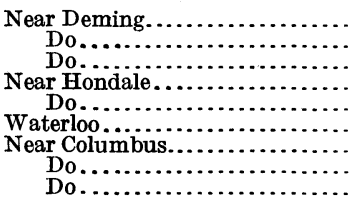 & $\begin{array}{r}49 \\
27-42 \\
52 \\
a \quad 45-50 \\
a \quad 67-70 \\
23-25 \\
2-7 \\
a \quad 6-12 \\
a 12-18\end{array}$ & $\begin{array}{r}1,250 \\
1,250 \\
350 \\
250 \\
500 \\
600 \\
1,500 \\
1,000 \\
1,200\end{array}$ & $\begin{array}{c}\$ 1.21 \\
1.43 \\
2.10 \\
4.20 \\
1.09 \\
1.70 \\
.48 \\
1.68 \\
.945\end{array}$ & $\begin{array}{l}2 \frac{1}{2} \\
3 \frac{1}{2} \\
4 \\
8 \frac{1}{2} \\
1 \frac{1}{2} \\
7 \\
7 \\
1 \frac{3}{4} \\
5 \frac{1}{2}\end{array}$ & $\begin{array}{l}\text { Naphtha, } 14 \text { cents. } \\
\text { Do. } \\
\text { Do. } \\
\text { Do. } \\
\text { Crude oil, } 4 \frac{1}{2} \text { cents. } \\
\text { Naphtha, } 14 \text { cents. } \\
\text { Do. } \\
\text { Do. } \\
\text { Do. }\end{array}$ \\
\hline
\end{tabular}

$a$ These are based on estimated drawdowns.

\section{RESULTS OF PUMPING TESTS.}

By A. T. Schwennesen.

Estimates of the yield from irrigating plants are usually based on the manufacturer's figures of the capacity of the pumps under certain ideal conditions. As such conditions seldom exist in actual practice, the yields are usually much overestimated. To obtain some reliable data in the Mimbres Valley, a series of five pumping tests were made during August and September, 1913.

The plants chosen for testing represent average types, and no attempt was made to select the largest or most efficient. Thus plants Nos. 1 and 3 are representative of the ordinary large plants, No. 2 is a good example of a plant of intermediate size, and No. 5 is an example of the smallest plants used in the district. Most of the existing plants are of the intermediate class represented by No. 2; few are larger in point of equipment than No. 1, although it has been reported that some afford much larger yields, and very few are smaller than No. 5 .

The discharge from the pumps was measured by a standard rectangular weir board set in the ditch. Simultaneous measurements of the head of water on the weir and of the drawdown in the well were made every 15 minutes during the test. The principal data obtained by these tests are given in the following table: 
Results of pumping tests in Luna County, N. Mex.

\begin{tabular}{|c|c|c|c|c|c|}
\hline & No. 1. & No. 2. & No. 3. & No. 4. & No. 5. \\
\hline 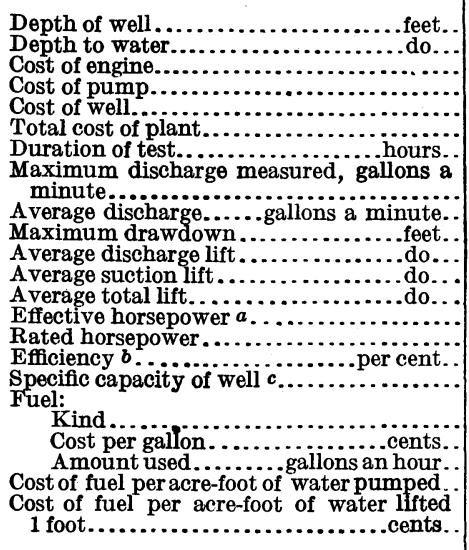 & $\begin{array}{r}75 \\
58.5 \\
\$ 1,680 \\
\$ 250 \\
\$ 1,145 \\
\$ 3,075 \\
1 \frac{5}{6} \\
898 \\
603 \\
10.2 \\
58.6 \\
15 \\
73.6 \\
11.2 \\
40 \\
28 \\
59 \\
\text { Distillate. } \\
6 \frac{1}{2} \\
2 \frac{1}{2} \\
\$ 1.46 \\
2\end{array}$ & $\begin{array}{r}67 \\
24.8 \\
\$ 550 \\
\$ 110 \\
\$ 978 \\
\$ 928 \\
1 \frac{1}{2} \\
558 \\
555 \\
11 \\
22.6 \\
14.3 \\
36.9 \\
5.18 \\
12 \\
43.2 \\
50 \\
\text { Distillate. } \\
9 \frac{1}{2} \\
1 \\
\$ 0.93 \\
2 \frac{1}{2}\end{array}$ & 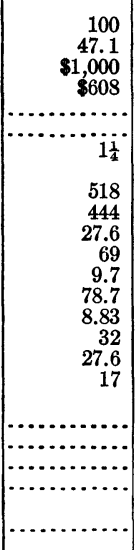 & 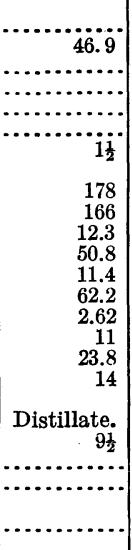 & 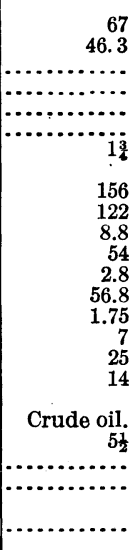 \\
\hline
\end{tabular}

a Effective horsepower $=\frac{\text { pounds of water pumped per minute } \times \text { total lift in feet }}{33,000}$

$b$ Efficiency $=\frac{\text { Effective horsepower }}{\text { Rated horsepower }}$

c Specific capacity is the yield (in gallons a minute) per foot of drawdown.

No. 1.-The plant of C. L. Baker (No. 1), in the SW. $\frac{1}{4}$ SE. $\frac{1}{4}$ sec. 4, T. $.24 \mathrm{~S} .$, R. $9 \mathrm{~W}$., is equipped with a 40-horsepower engine manufactured by the Bessemer Gas Engine Co., of Grove City, Pa., and designed to burn crude oil and the cheaper grades of distillate. The pump is a Blackham-Seale single-stage vertical centrifugal pump with a 19-inch runner. The pump is set 53 feet below the ground surface and is connected with the engine through a vertical shaft and belt.

The well is dug 75 feet deep. It was originally bored 115 feet deeper, but the bored part was afterward filled in. For the first 52 feet the cross section is 9 by 9 feet, for the next 18 feet it is 5 by 5 feet, and for the last 5 feet it is 4 by 4 feet. The well is curbed from top to bottom with planks. No complete log of the well was obtained, but the owner stated that the materials passed through were yellow clay and gravels in alternate layers. The clay beds averaged about 10 feet in thickness and the interbedded gravels from 1 to 4 feet. Two gravel beds near the bottom separated by 12 feet of clay and sand furnish most of the water. The cost of the well as given by the owner is as follows:

Constructing 75 feet of dug well..................... $\$ 800$

Boring 12-inch hole, 115 feet, at $\$ 1 \ldots \ldots \ldots \ldots \ldots \ldots \ldots \ldots \ldots \ldots \ldots \ldots$

Casing, 12-inch, 115 feet, at $\$ 2 \ldots \ldots \ldots \ldots \ldots \ldots \ldots \ldots \ldots \ldots .230$ 
The cost of the dug part of this well was excessive, and ordinarily a well of this kind costs much less.

This plant irrigates about 30 acres. The principal crops are alfalfa and beans. Five cuttings of alfalfa a year, yielding from $1 \frac{1}{4}$ to $1 \frac{1}{2}$ tons an acre a cutting, are usually obtained. Each crop requires two waterings. From 6 to 7 acres of alfalfa can be irrigated during a 10-hour pumping day.

No. 2.-The plant of J. M. Graham (No. 2), at the northwest corner of sec. 11, T. $24 \mathrm{~S} .$, R. $8 \mathrm{~W}$., is equipped with a 12-horsepower Fairbanks-Morse engine, belted to the vertical shaft of a single-stage vertical American centrifugal pump set at the bottom of a 22-foot pit. The engine is designed to burn gasoline and the higher grades of distillate.

The first 22 feet of the well is dug 9 by 5 feet in cross section and the remaining 45 feet bored 22 inches in diameter. The dug part is curbed with pine lumber and the bored part is cased with perforated casing. The owner reports the following log for the well:

Log of well in the northwest corner of sec. 11, T. $24 S ., R .8 \mathrm{~W}$.

\begin{tabular}{|c|c|c|}
\hline & $\begin{array}{l}\text { Thick- } \\
\text { ness. }\end{array}$ & Depth. \\
\hline 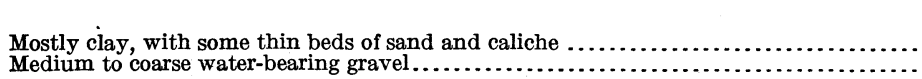 & $\begin{array}{r}\text { Feet. } \\
56 \\
11\end{array}$ & $\begin{array}{r}\text { Feet. } \\
\quad{ }_{66} \\
67\end{array}$ \\
\hline
\end{tabular}

The cost of constructing the well was as follows:

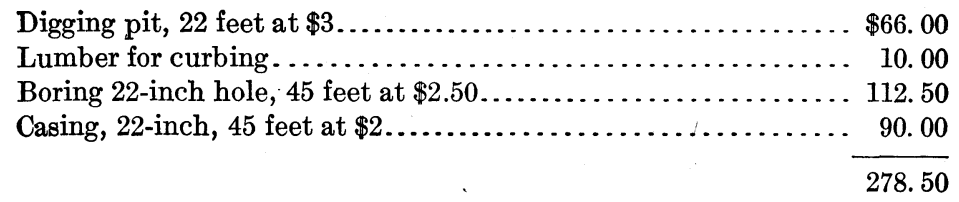

This plant furnishes water for 10 acres of alfalfa.

No. 3.-The equipment of the plant of M. L. McBride (No. 3), in the NW. $\frac{1}{4}$ SW. $\frac{1}{4}$ sec. 30 , T. 24 S., R. 8 W., consists of a 32horsepower Fairbanks-Morse engine using crude oil and the cheaper grades of distillate. A No. 5 Layne \& Bowler pump is set 65 feet below the surface and connected to the engine at the surface through a belt and vertical transmission shaft. The pump, with 20 feet of $7 \frac{5}{8}$-inch suction pipe and 70 feet of $8 \frac{5}{8}$-inch discharge pipe, cost $\$ 608.50$ f. o. b. at Deming.

Three water-bearing strata were penetrated in the well in a total depth of approximately 100 feet. The following log was furnished by the owner: 
Log of well in the NW. $\frac{1}{4} S W . \frac{1}{4} \sec .30, T .24 S ., R .8 W$.

\begin{tabular}{|c|c|c|}
\hline & $\begin{array}{l}\text { Thick- } \\
\text { ness. }\end{array}$ & Depth. \\
\hline 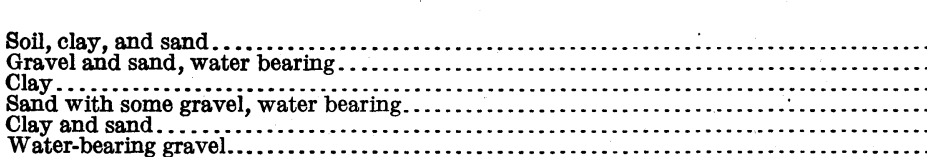 & \begin{tabular}{r|r} 
Feet. \\
64 \\
6 \\
2 \\
10 \\
18 \\
$(?)$
\end{tabular} & $\begin{array}{r}\text { Feet. } \\
64 \\
70 \\
72 \\
82 \\
100\end{array}$ \\
\hline
\end{tabular}

The plant irrigates 20 acres of beans and 5 acres of maize. The beans are watered three times during the four months of the growing season. One watering takes from 75 to 90 hours of continuous pumping.

No. 4. -The plant of M. W. Hollinshead (No. 4), in the NE. $\frac{1}{4}$ NE. 1 sec. 10, T. 26 S., R. 10 W., is equipped with an 11-horsepower Foos engine, burning gasoline and the better grades of distillate. The pump is a vertical single-stage centrifugal pump, set at water level in a pit and connected to the engine at the surface through a belt and vertical shaft.

The well consists of a 47-foot dug pit curbed with lumber. From the bottom of the pump pit the well is bored and cased with perforated casing.

The plant irrigates 20 acres of beans, Indian corn, and milo maize.

No. 5. - The plant of E. S. Deane (No. 5), at the northwest corner of the SE. $\frac{1}{4}$ sec. 2, T. 24 S., R. 9 W., is run by a 7-horsepower Simple engine, manufactured at Trinidad, Colo. Crude oil and the cheaper grades of distillate are used for fuel. The pump is a Buffalo No. 2 single-stage vertical centrifugal pump with a 12-inch runner. It is set at the bottom of a 53-foot pit and connected with the engine through a vertical shaft and belt. The well contains one waterbearing stratum. From the bottom of the pit a 15-inch hole cased with perforated casing extends down for 14 feet. The following log was reported:

Log of well in the SE. $\frac{1}{4}$ sec. 2, T. 24 S., R. 9 W.

\begin{tabular}{|c|c|c|}
\hline & $\begin{array}{c}\text { Thick- } \\
\text { ness. }\end{array}$ & Depth. \\
\hline 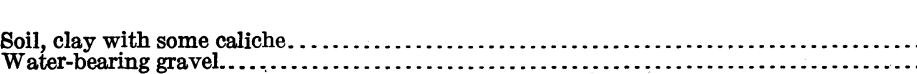 & $\begin{array}{r}\text { Feet. } \\
65 \\
2\end{array}$ & $\begin{array}{r}\text { Feet. } \\
65 \\
67\end{array}$ \\
\hline
\end{tabular}

This plant is operated in connection with a small earth reservoir and furnishes water for 5 to 8 acres of alfalfa, melons, and garden truck. 
